TITLE:

\title{
MARINE INSECTS OF THE TOKARA ISLANDS -IV. BITING MIDGES (DIPTERA, HELEIDAE)-
}

$\operatorname{AUTHOR}(S):$

Komyo, Etsuko

\section{CITATION:}

Komyo, Etsuko. MARINE INSECTS OF THE TOKARA ISLANDS -IV. BITING MIDGES (DIPTERA, HELEIDAE)-. PUBLICATIONS OF THE SETO MARINE BIOLOGICAL LABORATORY 1955, 4(23): $371-372$

ISSUE DATE:

1955-05-30

URL:

http://hdl.handle.net/2433/174512

RIGHT: 


\title{
MARINE INSECTS OF THE TOKARA ISLANDS
}

\section{BITING MIDGES (DIPTERA, HELEIDAE) ${ }^{1 ; 2)}$}

\author{
ETSUKo KŌMYŌ \\ Entomological Laboratory, Saikyo University
}

With one Text-figure

The present paper deals with the biting midges collected by Mr. S. Mryamoto and Mr. S. UÉNo at the Tokara Islands, Ryukyu. These midges are identified as follows:

\section{Culicoides arakawae (ARAKAwA) \\ 2. Culicoides maculatus (SHIRAKI) \\ 3. Culicoides amamiensis (TOKUNAGA)}

These species are all new records for these islands.

I wish to express my deepest thanks to Prof. Dr. Masaaki Tokunaga, the Chief of our Entomological Laboratory, for his kind direction on this work, and to Messrs. S. MiYamoto and S. UÉNo for their kindness in collecting these biting midges.

\section{Culicoides arakawae (ARAKAWA)}

This midge is very widely distributed in Japan and Formosa. Dr. T. Shiraki (1931) reported the female from Formosa as C. sugimotonis. Dr. S. Matsumura (1915 and 1932) also reported from Shikoku as Ceratopogon arakawae and Dr. M. Tokunaga (1937) described it in detail.

Specimens:- Two females; Takarajima; May 30, 1953.

\section{Culicoides maculatus (SHIRAKI)}

This midge has been recorded by Dr. T. SHIRAKI (1913) only from Formosa as Ceratopogon maculatus, by Dr. J. J. KIEFFER (1916) as Culicoides tainana and by Dr. M. Tokunaga (1937) as C. maculatus.

Specimen:- One female; Nakanoshima, June 4, 1953.

1) Scientific Survey of the Tokara Islands, Report No. 18.

2) Contributions from the Entomological Laboratory, Saikyo University, Kyoto, No. 27.

Publ. Seto Mar. Biol. Lab., IV (2-3), 1955. (Article 32) 


\section{Culicoides amamiensis ToKUNAGA}

This species has been reported in detail by Dr. M. Tokunaga (1937) from AmamiOshima. Here I intend to complete his description with my observation.

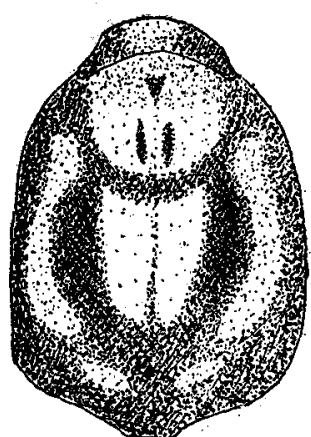

Culicoides amamiensis TOKUNAGA.

Fig. 1. Dorsal thoracic pattern.

In dry state, thorax (Fig. 1) pruinose, slightly dark brown, provided with yellow setae and yellowish or pale brown pattern. Scutum with a pair of small pale brown spots on humeral pits, a pair of pale brown stripes on lateral parts, a large yellowish brown pattern on median part, a large slightly greyish or pale brown pattern including three small brown spots on caudal part. Scutellum grey, paler on median part. Halteres white. Abdomen pale brown or yellow. Spermathecae two, almost spherical, unequal.

Specimen:- One female; Nakanoshima; June 4, 1953.

\section{LITERATURE}

Tokunaga, M. 1937. Sand flies (Ceratopogonidae, Diptera). Tenthredo/Acta Ent., 1 (3): 286$289,290-295$ and $325-327$.

1940. Biting midges from Japan and neighbouring countries, including Micronesian Islands, Manchuria, North China and Mongolia. Tenthredo/Acta Ent., 3 (2): 145. 